\title{
Temperatured dependent transitions in several phospholipids measured by ellipsometry
}

Citation for published version (APA):

Cuypers, P. A., Janssen, M. P., Kop, J. M. M., Hermens, W. TH., \& Hemker, H. C. (1980). Temperatured dependent transitions in several phospholipids measured by ellipsometry. Surface Science, 96(1-3), 555563. https://doi.org/10.1016/0039-6028(80)90326-X

Document status and date:

Published: 01/06/1980

DOI:

10.1016/0039-6028(80)90326-X

Document Version:

Publisher's PDF, also known as Version of record

\section{Please check the document version of this publication:}

- A submitted manuscript is the version of the article upon submission and before peer-review. There can be important differences between the submitted version and the official published version of record.

People interested in the research are advised to contact the author for the final version of the publication, or visit the DOI to the publisher's website.

- The final author version and the galley proof are versions of the publication after peer review.

- The final published version features the final layout of the paper including the volume, issue and page numbers.

Link to publication

\footnotetext{
General rights rights.

- You may freely distribute the URL identifying the publication in the public portal. please follow below link for the End User Agreement:

www.umlib.nl/taverne-license

Take down policy

If you believe that this document breaches copyright please contact us at:

repository@maastrichtuniversity.nl

providing details and we will investigate your claim.
}

Copyright and moral rights for the publications made accessible in the public portal are retained by the authors and/or other copyright owners and it is a condition of accessing publications that users recognise and abide by the legal requirements associated with these

- Users may download and print one copy of any publication from the public portal for the purpose of private study or research.

- You may not further distribute the material or use it for any profit-making activity or commercial gain

If the publication is distributed under the terms of Article $25 \mathrm{fa}$ of the Dutch Copyright Act, indicated by the "Taverne" license above, 


\title{
TEMPERATURE DEPENDENT TRANSITIONS IN SEVERAL PHOSPHOLIPIDS MEASURED BY ELLIPSOMETRY
}

\author{
P.A. CUYPERS, M.P. JANSSEN, J.M.M. KOP and W.TH. HERMENS \\ Department of Biophysics, State University of Limburg, Maastricht, The Netherlands
}

and

H.C. HEMKER

Department of Biochemistry, Biomedical Centre, State University of Limburg, Maastricht, The Netherlands

Received 20 August 1979

The technique of producing regular multilayers of phospholipids according to the LangmuirBlodgett method is developed. The temperature dependency of thickness and refractive index of multilayers of 1,2-dimyristoyl-sn-glycero-3-phosphoserine (14:0/14:O PS) as a function of ionic strength is described and compared with the behavior of randomly oriented layers of 1,2 dipalmitoyl-sn-glycero-3-phosphocholine (16:O/16:O PC). Multilayers of $14: 0 / 14:$ O PS show several transitions that are dependent on ionic strength. Some of these transitions are not detectable by the usual technique of differential scanning calorimetry because the enthalpy consumed in the transitions is too low.

\section{Introduction}

The interaction between proteins and phospholipids plays a crucial role in the process of bloodclotting, yet our understanding on a molecular level is still fragmentary.

Although there is conclusive evidence that a negative surface charge of the phospholipids is required for coagulant activity, neither the magnitude of the charge nor the charge density alone are sufficient to account for the ability of the lipids to form a procoagulant surface.

For instance, a direct relationship with the lipid phase transition was recently established by Tans et al. [1] who compared the clot promoting behavior of synthetic mixtures of phosphatidyl serine and phosphatidyl choline with their phase transitions as observed in calorimetry. The results demonstrate that membrane fluidity is as important as a small negative surface charge for full procoagulant activity of the phospholipid/water interface. To study protein-phospholipid interactions occurring at the surface of phospholipid vesicles by means of ellipsometry, we have to construct a surface simulating the outer vesicle membrane which is 
known to consist of ordered phospholipid multilayers.

To this end we first obtained a preparation consisting of regular phospholipid multilayers deposited upon a chromium slide. This preparation allows detailed study of temperature-dependent transitions which have been the object of much calorimetric work.

\section{Materials and methods}

\subsection{Materials}

The following phospholipids were used:

1,2-dipalmitoyl-sn-glycero-3-phosphocholine (16:0/16: O-phosphatidylcholine); 1,2-dimyristoyl-sn-glycero-3-phosphoserine (14:0/14 : O-phosphatidylserine).

Phosphatidylcholine was prepared by reacylating the cadmium chloride adduct of sn-glycero-3-phosphocholine with palmitic-acyl chloride according to the method of Bear and Buchnea [2]. Phosphatidyl serine was prepared from phosphatidylcholine by enzymatic synthesis as described by Comfurius and Zwaal [3]. All chemicals used were Merck P.A. Chromium-coated glass slides were manufactured by Stabilix, The Hague, The Netherlands.

\subsection{Methods}

\subsubsection{Production of multilayers}

Phosphatidylserine (14:0/14: O PS) can be spread as a monomolecular layer on water and then transferred to a solid substrate, layer by layer, by repeatedly dipping and withdrawing the substrate vertically through the air/water interface. With this so called Langmuir-Blodgett technique [4] any number of layers can be deposited on such a substrate. The solid substrate was a chromium coated glass slide.

\subsubsection{Production of randomly oriented films}

Chromium-coated glass slides were cleaned with chloroform, and a small drop $(5 \mu \mathrm{l})$ of phospholipid dissolved in chloroform $(7 \mathrm{mg} / \mathrm{ml})$ was put near the end of one slide, the holder, which is kept horizontal. A second slide, the spreader, is held at an angle of (say) $30^{\circ}$ to the horizontal, its long axis parallel to that of the holder. The lower edge of the spreader is placed on the surface of the holder so that the drop is beneath it. The spreader slide is then moved slowly toward the drop until contact is made, whereupon the solution flows evenly along the area of contact. The spreader is then pulled back rapidly and smoothly, but still on the surface of the holder. The thickness of the resulting film depends on the rate of movement of the spreader slide and the angle at which the spreader is held; a larger angle makes a thicker film.

The principle of this technique is used in hematology to study blood films. 


\subsubsection{Ellipsometer (instrument)}

We modified a Rudolf ellipsometer, type 43303-200E. The instrument is automatized by computer-steered stepping motors on the analyzer and polarizer. The minimalization procedure is an automatized manual procedure. The procedure consists of finding the analyzer position that gives minimal light transmission at a fixed polarizer position, then fixing the analyzer, changing the polarizer, and so on. This procedure continuously follows changes of the minimum up to a velocity of about $1.5 \mathrm{deg} / \mathrm{s}$, but changes observed in actual experiments did not exceed $0.2 \mathrm{deg} / \mathrm{s}$.

By this method of automatization we can measure one position every two or three seconds. The accuracy and reproducibility is within $0.01^{\circ}$. Complete description of the apparatus and method we use are given in refs. $[5,8]$.

\subsubsection{Calculation technique}

The refractive index $n$ and thickness $d$ are calculated directly from observed $\Delta$ and $\psi$ values by an iterative procedure [7]. Substitution of the explicit expression for the total reflection coefficients $R^{\mathrm{p}}$ and $R^{\mathrm{s}}$ into the equation

$R^{\mathrm{p}} / R^{\mathrm{s}}=\tan \psi \exp (\mathrm{j} \Delta)$,

yields a quadratic form from which a complex value of $d$ can be calculated for given $n$. The correct value of $d$ is real, so $n$ is adjusted such that the imaginary part of $d$ is minimized.

\section{Results}

\subsection{Stacked multilayers of $14: 0 / 14:$ O PS}

Any number of $14: 0 / 14:$ O PS layers can be deposited on a chromium slide in water containing less than $1 \mu \mathrm{mol} \mathrm{Ca}^{2+}$. The conditions to be fulfilled are a subphase (water) pH between 5 and 5.4, a surface pressure of 25-40 dyn $/ \mathrm{cm}$ and a low diping speed ( $4-5 \mathrm{~mm} / \mathrm{min}$ ).

The optical properties of these multilayers show some variation when measured in air by ellipsometry. Thickness and refraction index of the first several layers show fluctuations (see fig. 1 and table 1). While the refractive index and thickness per layer of a 30-layer system range between $n=1.49-1.51$ and $d=24.5-28.0 \AA$. Similar variations are found for multilayers of Ba-stearate [6-8]. When measured in water these variations were much smaller and no significant deviation of the first few layers were observed. The results of 12 experiments in this study were $d=$ $25.9 \pm 0.4 \AA$ and $n=1.503 \pm 0.002$ (mean \pm SEM, $n=12$ ).

Preparating multilayers of $16: 0 / 16: 0 \mathrm{PC}$ was not feasible. The first layer is transferred to the chromium slide under the same conditions as $14: 0 / 14:$ O PS. This layer remains on the slide but no other layers adhere to the first. The thick- 


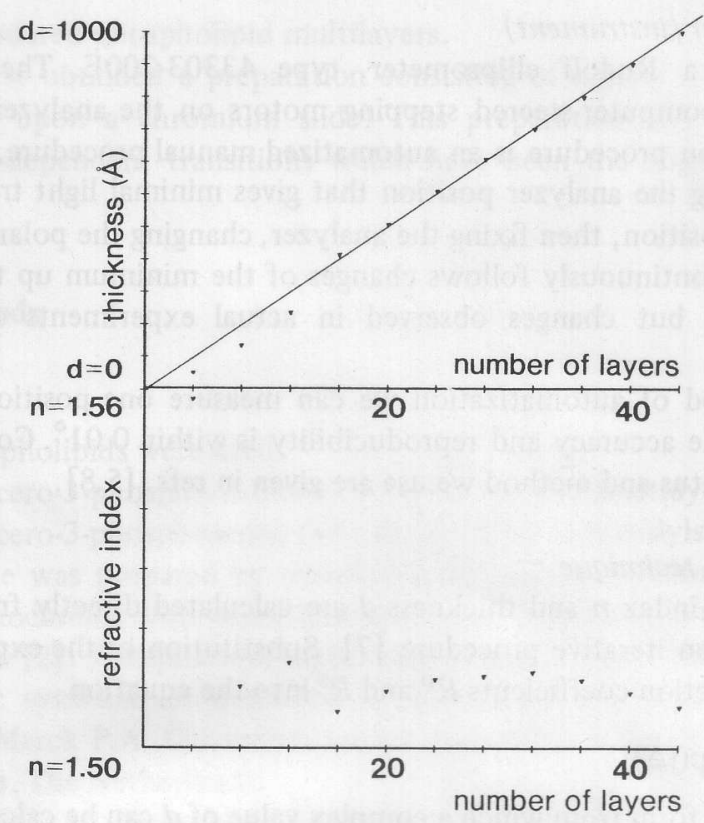

Fig. 1. Stacked layers of $14: 0 / 14: 0$ phosphatidylserine on a chromium coated glass slide. Measured in air.

Table 1

Stacked layers of di- $\mathrm{C}_{14-\mathrm{O}} \mathrm{PS}$

\begin{tabular}{rlr}
\hline $\begin{array}{l}\text { Number } \\
\text { of layers }\end{array}$ & $\begin{array}{l}\text { Refractive } \\
\text { index }\end{array}$ & Thickness \\
\hline 4 & 1.560 & 67.9 \\
8 & 1.510 & 177.1 \\
12 & 1.514 & 277.5 \\
16 & 1.506 & 454.3 \\
20 & 1.509 & 547.1 \\
24 & 1.511 & 647.8 \\
28 & 1.512 & 746.0 \\
32 & 1.512 & 837.9 \\
36 & 1.511 & 933.8 \\
40 & 1.509 & 1035.4 \\
44 & 1.507 & 1131.3 \\
\hline
\end{tabular}


ness and refractive index of the first monolayer is hard to calculate because the accuracy is not high enough to discriminate between different refractive indexes. These thin layers of $16: 0 / 16: 0$ PC could not be used to study temperature behavior, so randomly oriented phospholipid films were used.

\subsection{Randomly oriented $16: 0 / 16: O P C$}

As a rough impression of the films we used, some numerical values of thickness and refractive index are:

$d=741 \AA, n=1.393 ; \quad d=1156 \AA, n=1.351 ; \quad d=1058 \AA, n=1.367$.

Starting with these layers we studied their temperature behavior.

\subsection{Temperature effects}

\subsubsection{Temperature effect on stacked monolayers of $14: 0 / 14: O$ PS}

The temperature was varied over a range of $20-50^{\circ} \mathrm{C}$. If the medium in the

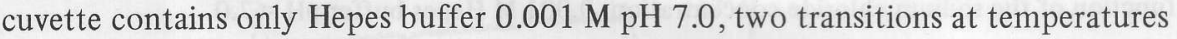

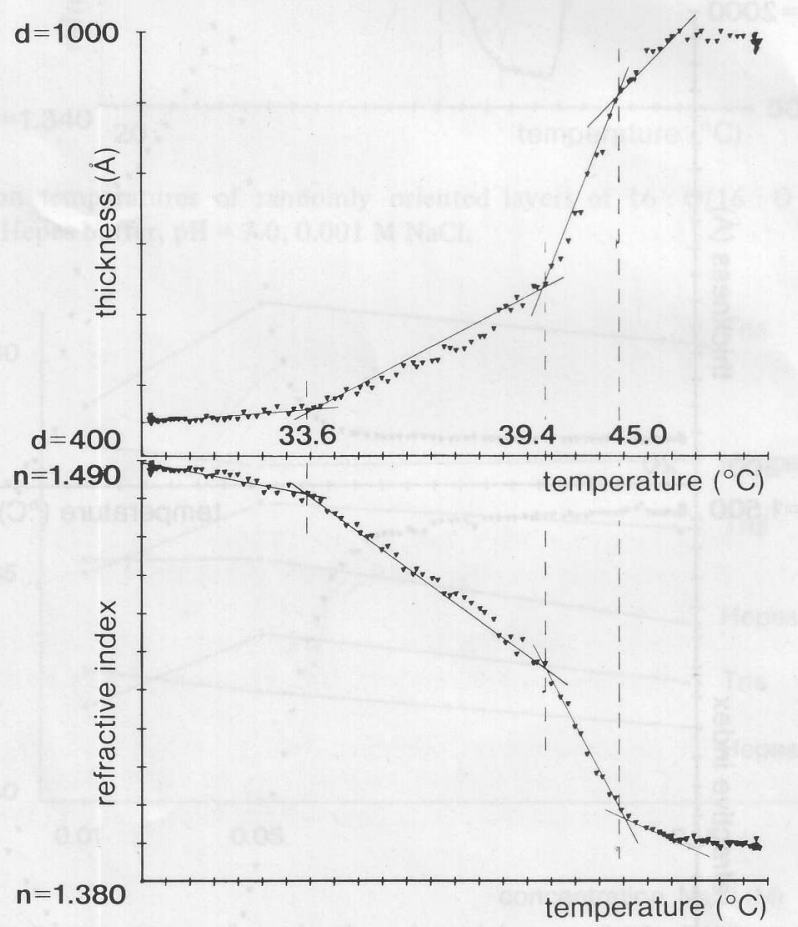

Fig. 2. Transition temperatures of stacked monolayers of $14: \mathrm{O} / 14: \mathrm{O}$ phosphatidylserine; $0.01 \mathrm{M}$ Hepes buffer, $\mathrm{pH}=7.0,0.02 \mathrm{M} \mathrm{NaCl}$. 


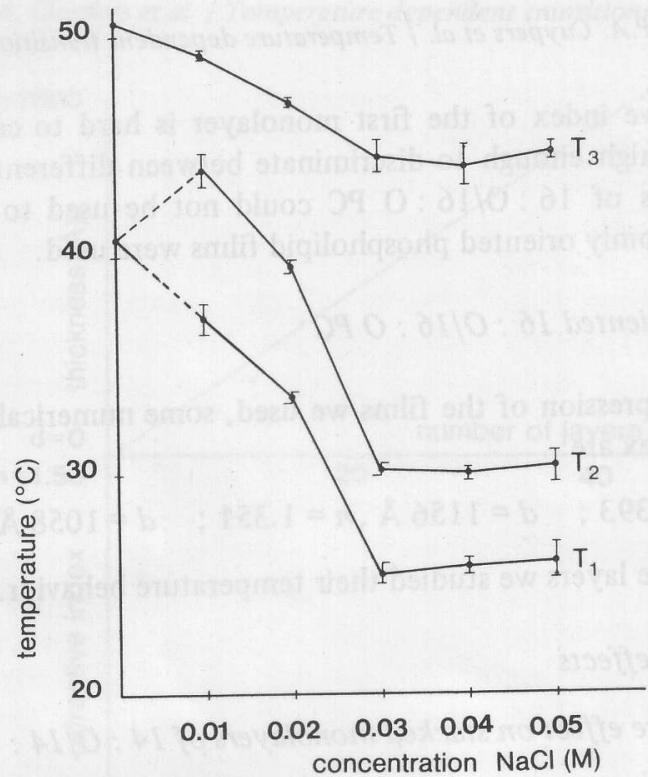

Fig. 3. Transition temperatures of stacked monolayers of $14: 0 / 14: 0$ phosphatidylserine as a function of the sodium chloride concentration; $0.001 \mathrm{M}$ Hepes buffer $\mathrm{pH}=7.0$.

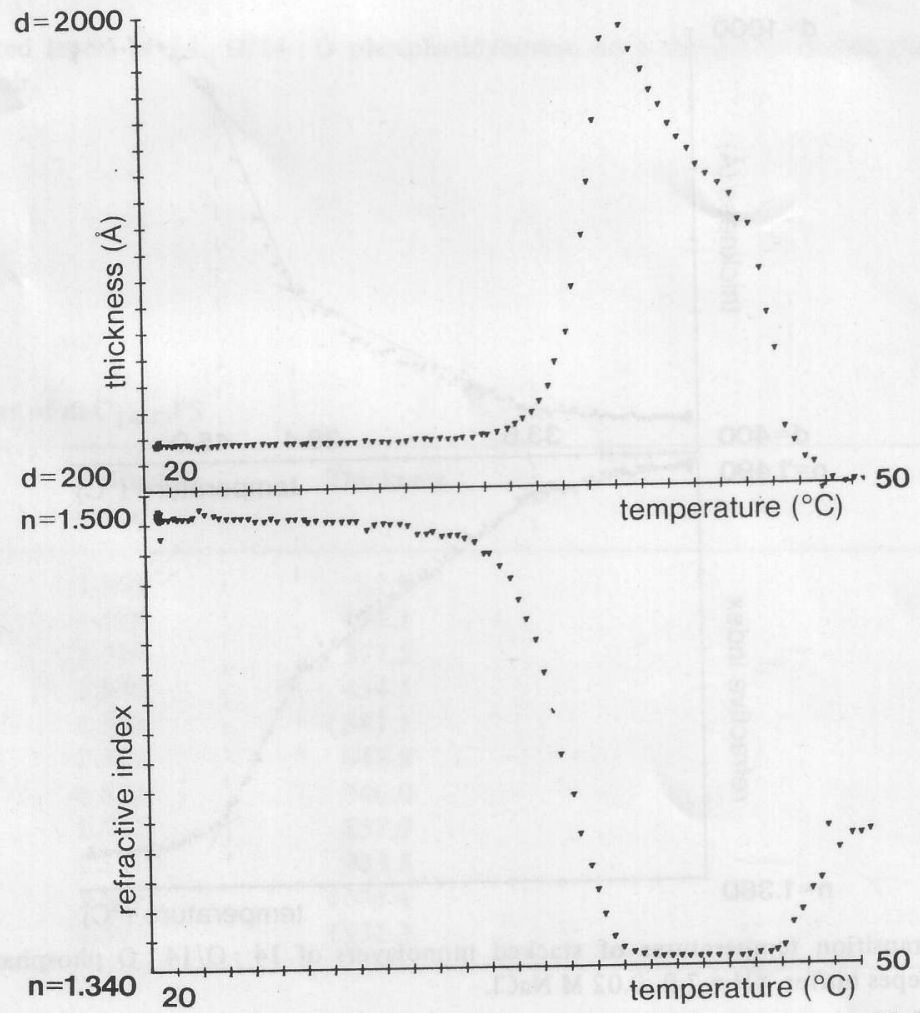

Fig. 4. Transition temperatures of stacked monolayers of $14: \mathrm{O} / 14: \mathrm{O}$ phosphatidylserine in the presence of $10 \mu \mathrm{M} \mathrm{Ca}^{2+} ; 0.001 \mathrm{M}$ Hepes buffer, $\mathrm{pH}=7.0,0.05 \mathrm{M} \mathrm{NaCl}$. 


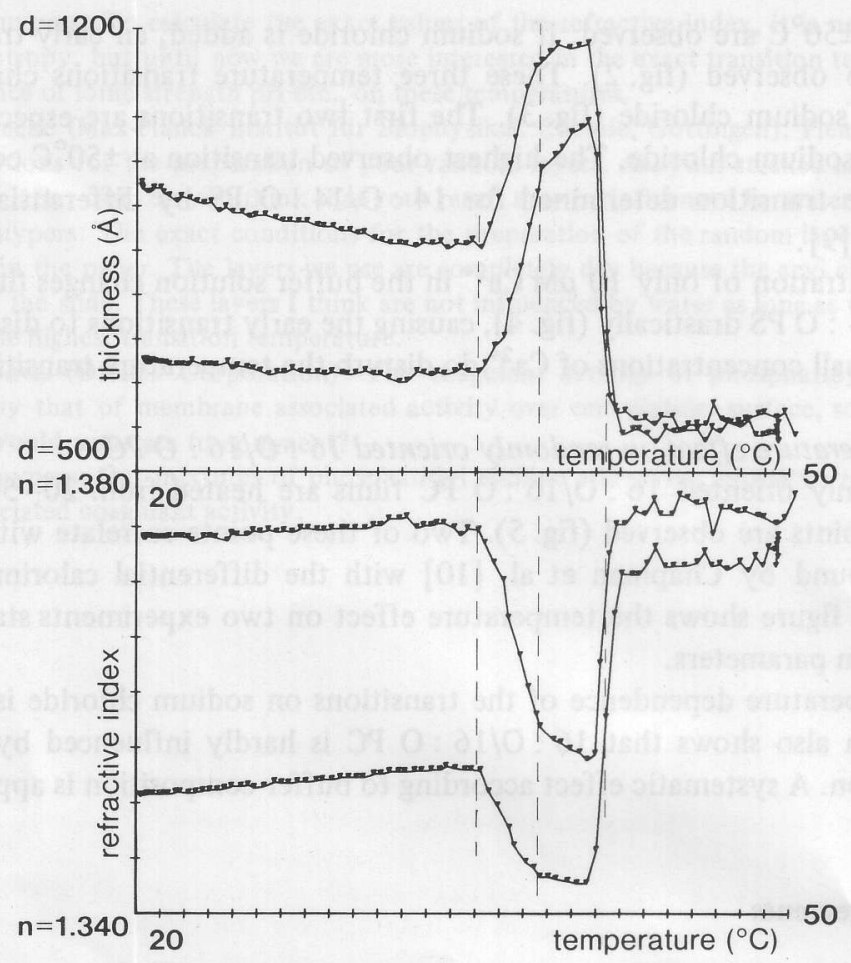

Fig. 5. Transition temperatures of randomly oriented layers of $16: \mathrm{O} / 16: 0$ phosphatidylcholine; $0.01 \mathrm{M}$ Hepes buffer, $\mathrm{pH}=7.0,0.001 \mathrm{M} \mathrm{NaCl}$.

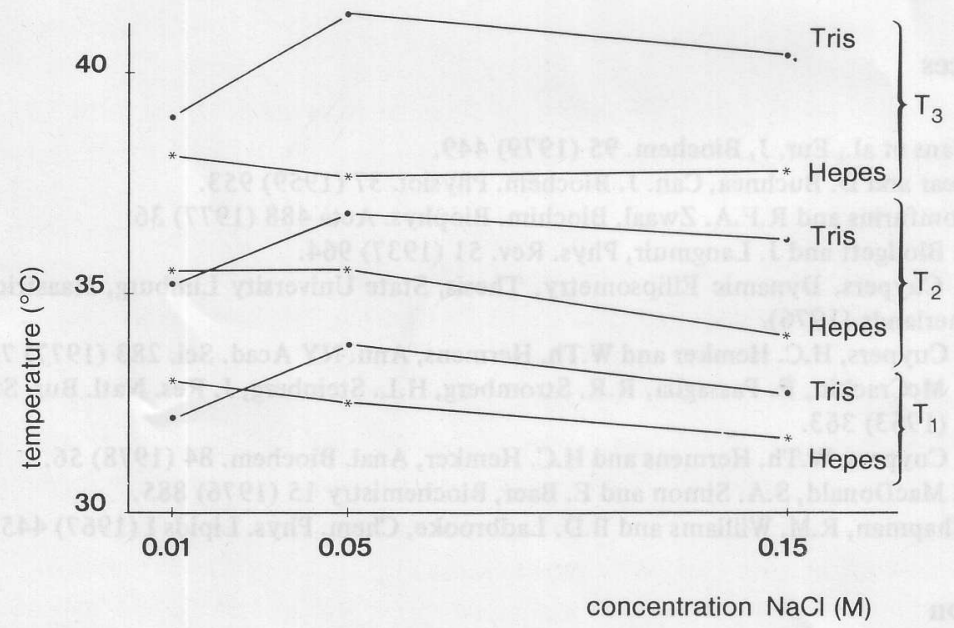

Fig. 6. Transition temperatures of randomly oriented layers of $16: 0 / 16: 0$ phosphatidylcholine as a function of the sodium chloride concentration; $0.01 \mathrm{M}$ Hepes buffer, $\mathrm{pH}=7.0$. 
at \pm 40 and $\pm 50^{\circ} \mathrm{C}$ are observed. If sodium chloride is added, an early transition at $\pm 30^{\circ}$ is also observed (fig. 2). These three temperature transitions change upon addition of sodium chloride (fig. 3). The first two transitions are especially more sensitive to sodium chloride. The highest observed transition at $\pm 50^{\circ} \mathrm{C}$ corresponds to the phase transition determined for $14: 0 / 14: 0$ PS by differential scanning calorimetry [9].

A concentration of only $10 \mu \mathrm{M} \mathrm{Ca}^{2+}$ in the buffer solution changes the behavior of $14: 0 / 14$ : O PS drastically (fig. 4), causing the early transitions to disappear. So even very small concentrations of $\mathrm{Ca}^{2+}$ do disturb the temperature transitions.

\subsubsection{Temperature effect on randomly oriented $16: O / 16: O P C$}

If randomly oriented $16: \mathrm{O} / 16: \mathrm{O}$ PC films are heated from $20-50^{\circ} \mathrm{C}$, three transition points are observed (fig. 5). Two of these points correlate with the temperatures found by Chapman et al. [10] with the differential calorimetry techniques. This figure shows the temperature effect on two experiments starting with different film parameters.

The temperature dependence of the transitions on sodium chloride is shown in fig. 6 , which also shows that $16: 0 / 16: \mathrm{O} \mathrm{PC}$ is hardly influenced by the $\mathrm{NaCl}$ concentration. A systematic effect according to buffer composition is apparent.

\section{Acknowledgements}

The authors are indebted to the Audio Visual Centre of the State University of Limburg and Mrs. R. Borgman for their help in preparing the manuscript.

\section{References}

[1] G. Tans et al., Eur. J. Biochem. 95 (1979) 449.

[2] E. Bear and D. Buchnea, Can. J. Biochem. Physiol. 37 (1959) 953.

[3] P. Comfurius and R.F.A. Zwaal, Biochim. Biophys. Acta 488 (1977) 36.

[4] K.B. Blodgett and J. Langmuir, Phys. Rev. 51 (1937) 964.

[5] P.A. Cuypers, Dynamic Ellipsometry, Thesis, State University Limburg, Maastricht, The Netherlands (1976).

[6] P.A. Cuypers, H.C. Hemker and W.Th. Hermens, Ann. NY Acad. Sci. 283 (1977) 77.

[7] F.L. McCrackin, E. Passaglia, R.R. Stromberg, H.L. Steinberg, J. Res. Natl. Bur. Std. (US) 67A (1963) 363.

[8] P.A. Cuypers, W.Th. Hermens and H.C. Hemker, Anal. Biochem. 84 (1978) 56.

[9] R.C. MacDonald, S.A. Simon and E. Baer, Biochemistry 15 (1976) 88.5.

[10] D. Chapman, R.M. Williams and B.D. Ladbrooke, Chem. Phys. Lipids I (1967) 445.

\section{Discussion}

G.A. Bootsma (Twente University of Technology): Should you not treat the layers of adsorbed elongated molecules as anisotropic instead of isotropic phases? 
P.A. Cuypers: To calculate the exact values of the refractive index, it is necessary to consider anisotropy, but until now we are more interested in the exact transition temperatures and the influence of ionic strength $\mathrm{pH}$ etc., on these temperatures.

E. Kruecke (Max-Planck Institut für Biophysikal. Chemie, Göttingen): Please let me know the instructions for the preparation of your random layers. Are your stacked layers dry or wet and, in the latter case, do you think that your result may be influenced by water?

P.A. Cuypers: The exact conditions for the preparation of the random layers is completely described in the paper. The layers we use are completely dry because the acyl chains are on the outside of the slide. These layers I think are not influenced by water as long as the temperature is below the highest transition temperature.

R.B. Davis (Dionex Corporation): The coagulant activity of phosphatidyl serine is not matched by that of membrane associated activity over one platelet surface, so called platelet factor 3. Would you care to comment?

P.A. Cuypers: Our mixtures of phosphatidyl choline and serine appear to reproduce membrane associated coagulant activity. 